\title{
Expression of c-Src and comparison of cytologic features in cherubism, central giant cell granuloma and giant cell tumors
}

\author{
CHANGNING WANG ${ }^{1,2^{*}}$, YALING SONG ${ }^{1,2 *}$, BIN PENG $^{2}$, MINGWEN FAN $^{2}$, \\ JIANG $\mathrm{LI}^{3}$, SHENGRONG ZHU ${ }^{4}$ and ZHUAN BIAN ${ }^{1,2}$ \\ ${ }^{1}$ Key Laboratory of Oral Biomedical Engineering, Ministry of Education of China, ${ }^{2}$ Department of Endodontics, \\ School and Hospital of Stomatology, Wuhan University, 237 Luoyu Road, Wuhan 430079; ${ }^{3}$ Department of \\ Oral Pathology, School and Hospital of Stomatology, Shanghai Second Medical University, 639 Zhizaoju Road, \\ Shanghai 200011; ${ }^{4}$ Department of Oral Maxillofacial Surgery, Tongji Hospital, \\ Huazhong Science and Technology University, 1095 Jiefang Road, Wuhan 430030, P.R. China
}

Received September 13, 2005; Accepted November 16, 2005

\begin{abstract}
Cherubism (CBM) and central giant cell granuloma (CGCG) of the jaw and giant cell tumor (GCT) of the long bone are clinically different diseases. Histologically, they are all multinucleated giant cell (MGC)-containing lesions. This study aims to evaluate the expression of c-Src and cytologic features in CBM, CGCG and GCT and to clarify whether there is a common mechanism underlying the formation of multi-nucleated giant cells (MGCs) in these lesions. Specimens and paraffin blocks were collected from patients with CBM (12 cases), CGCG (24 cases) and GCT (37 cases). Histomorpho-metric differences in MGCs were compared among the three types of lesions. The expression of c-Src by immunohistochemistry and in situ hybridization and the expression of TRAP by enzyme histochemical staining were examined. Expression of c-Src mRNA and protein, as well as TRAP staining, was detected in both MGCs and a fraction of mononuclear cells in all investigated lesions. There are no quantitative differences for cytologic features and c-Src expression among the lesions. The results suggested that CBM, CGCG and GCT have overlapping cytological features at the histological level, and c-Src may be involved in the formation of MGCs in the three different diseases.
\end{abstract}

Correspondence to: Professor Zhuan Bian, School and Hospital of Stomatology, Wuhan University, 237 Luoyu Road, Wuhan 430079, P.R. China

E-mail: kqyywjtx@public.wh.hb.cn

${ }^{*}$ Contributed equally

Abbreviations: CBM, cherubism; CGCG, central giant cell granuloma; GCT, giant cell tumor; MGCs, multinucleated giant cells

Key words: cherubism, central giant cell granuloma, giant cell tumor, c-Src

\section{Introduction}

Cherubism (CBM) is a non-neoplastic bone disease characterized by obvious bilateral, painless enlargement of the jaw in children and young adults $(1,2)$. It is generally inherited as an autosomal dominant trait with a penetrance of $80 \%$ and variable expressivity (3), however, sporadic cases were also reported $(4,5)$. Histologically, the lesions contain numerous multinuclear giant cells (MGCs) scattered throughout a fibrous connective tissue stroma (6). The pathogenesis and nature of CBM is uncertain.

Similar areas with giant cell accumulation can also be seen in central giant cell granuloma (CGCG) and giant cell tumors (GCT) of bone $(7,8)$. CGCG is usually considered a benign solitary osteolytic lesion of the jaw, which often involves the anterior mandible and crosses the midline. It is primarily diagnosed in patients aged between 10 and 30 years with a predilection for females. GCT, as a true neoplasm, commonly presents as a painful, slow-growing, expansile unilocular or multilocular benign lesion located in the metaphyseal end of a long bone or is adjacent to the ossified epiphyseal line, occasionally with metastasis and malignant transformation (9). Most patients are aged between 20 and 40 years, and women are more frequently affected. GCT rarely involves the jaw bone, and little is known about the appearance of GCT in the jaw $(6,10)$.

Although defined as different entities, the three lesions histologically contain multinucleated giant cells within a cellular and fibrous connective tissue stroma. Previous investigations demonstrated that MGCs in CBM, CGCG and GCT exhibit phenotypic characteristics of osteoclasts, including expression of tartrate-resistant acid phosphatase (TRAP) and the receptor activator of nuclear factor $\mathrm{\kappa B}$ (RANK) $(11,12)$. RANK signaling is essential for the differentiation and activation of osteoclasts (13). The Src protein, which is required for osteoclast activation in vitro, has been shown to bind to TRAF6 and allow RANK-mediated signaling pathways to induce cell survival, cytoskeletal rearrangements and motility (14). The crucial role of the RANK/TRAF6-Src pathway in osteoclastogenesis prompted us to hypothesize 
Table I. Summary of clinical features of cases with CBM, CGCG and GCT.

\begin{tabular}{|c|c|c|c|c|c|c|c|c|c|}
\hline \multirow[b]{2}{*}{ Lesion } & \multirow{2}{*}{$\begin{array}{l}\text { Cases } \\
\text { (n) }\end{array}$} & \multicolumn{2}{|c|}{ Age (years) } & \multicolumn{2}{|c|}{ Gender (n) } & \multirow{2}{*}{$\begin{array}{c}\text { Familial } \\
\text { involvement (n) }\end{array}$} & \multicolumn{3}{|c|}{ Location } \\
\hline & & Range & Mean $\pm \mathrm{SD}^{\mathrm{a}}$ & Male & Female & & Maxilla & Mandible & Long bone \\
\hline $\mathrm{CBM}$ & 12 & $5-18$ & $9.1 \pm 3.1$ & 7 & 5 & 8 (4 sporadic) & 3 & 9 & 0 \\
\hline CGCG & 24 & $11-57$ & $21.5 \pm 4.8$ & 11 & 13 & None & 6 & 18 & 0 \\
\hline GCT & 37 & $15-59$ & $23.5 \pm 4.1$ & 20 & 17 & None & 0 & 0 & 37 \\
\hline
\end{tabular}

${ }^{\mathrm{a}} \mathrm{P}<0.05$.

that c-Src might be involved in MGC formation in these giantcell-rich diseases.

The purpose of this study was to evaluate and compare the expression of c-Src by immunohistochemistry and in situ hybridization and expression of TRAP by enzyme histochemical staining in CBM, CGCG and GCT, and elucidate whether there is a common mechanism underlying the formation of MGCs in the three different diseases. Moreover, because of difficulties in distinguishing microscopic findings among CBM, CGCG and GCT, a comparative analysis of cytologic features was performed to assess whether there are differences and specific features at the histological level for the three lesions.

\section{Materials and methods}

Clinical materials. The study protocol was approved by the Institutional Review Board of Wuhan University. The materials consisted of formalin-fixed paraffin-embedded tissue samples from patients who were surgically treated for CBM, GCGG and GCT. The 12 cases of CBM and 24 cases of CGCG in the jaw were retrieved from the files of the Hospital of Stomatology of Wuhan University and Shanghai Second Medical University from 1980 to 2005. Cases of GCT in the long bone $(n=37)$ were randomly chosen from the files of the Department of Pathology in Tongji Hospital, Huazhong Science and Technology University from 1990 to 2005. By convention, this study will hereafter refer to the long bone lesion as GCT and the jaw lesion as CGCG or CBM. Clinical information, including the gender and age of each patient, familial history and site of the lesion, were recorded. Serial $5-\mu \mathrm{m}$ thick sections were cut from paraffin blocks for each case and placed onto slides. Some sections were stained with hematoxylin and eosin $(\mathrm{H} \& \mathrm{E})$ using standard procedures, and others were prepared for examination. The preparation of sections and histological assay were performed by two examiners blinded to the clinical results.

Immunohistochemistry. Serial tissue sections were deparaffinized and rehydrated, then rinsed in $0.01 \mathrm{M}$ phosphate-buffered saline (PBS; pH 7.4). Endogenous peroxidase activity was blocked by incubating the slides in $0.3 \%$ hydrogen peroxide with methanol for $30 \mathrm{~min}$ at room temperature. For antigen retrieval, the sections were microwaved in $0.1 \mathrm{M}$ sodium citrate buffer ( $\mathrm{pH} 6.0$ ) at $100^{\circ} \mathrm{C}$ for $10 \mathrm{~min}$, and subsequently cooled to $30^{\circ} \mathrm{C}$. After washing in PBS, the slides were preincubated with $10 \%$ non-immune goat serum for $15 \mathrm{~min}$ at room temperature to prevent non-specific protein binding. Subsequently, sections were incubated at $4{ }^{\circ} \mathrm{C}$ overnight with 1:150 diluted rabbit anti-Src polyclonal antibody (Sigma, St. Louis, MO, USA). In negative controls, the antibody was substituted by PBS. The standard streptavidin-biotin-peroxidase complex method was performed to bind the primary antibodies with the use of SABC kits (Boster Co., Wuhan, China). The brown reaction products were visualized by immersing the sections in DAB reagent $(0.06 \%$ 3,3-diaminobenzidine tetrahydrochloride and $0.03 \% \mathrm{H}_{2} \mathrm{O}_{2}$ in phosphate-citrate buffer). Sections were then counterstained with Mayer's hematoxylin for $3 \mathrm{~min}$ and mounted.

In situ hybridization. A cocktail probe of c-Src anti-sense oligo-DNA (5'-ACAAG AGCAA GCCCA AGGAT GCCAG CCAGC-3', 5'-TTTGG CAAGA TCACC AGACG GGAGT CAGAG-3', and 5'-CACCT TCGAG TACCT GCAGG CCTTC CTGGA-3') was synthesized (Boster Co., Wuhan, China), and complemented the human c-Src mRNA (CDS; 7-36 bp, 457-486 bp and 1531-1560 bp, respectively). The sense oligo-DNAs corresponding to these mRNA sequences were selected as negative control probes. A computer-assisted search of the oligo-DNA sequences found no significant homology with any known sequences. The oligo-DNAs were labeled by digoxigenin with terminal transferase (Sigma).

Hybridization was performed on serial tissue slides according to the manufacturer's instructions. The deparaffinized and rehydrated slides were first incubated for $30 \mathrm{~min}$ in $0.3 \%$ hydrogen peroxide, washed with water, and then digested with pepsin for $20 \mathrm{~min}$ at $37^{\circ} \mathrm{C}$. After $2 \mathrm{~h}$ prehybridization, a volume of $20 \mu 1$ hybridization solution containing $2 \mu \mathrm{l}$ of labled oligo-DNA probes was added to each section, and slides underwent hybridization in a humid chamber at $38^{\circ} \mathrm{C}$ overnight under coverslips. The anti-sense oligo-DNA probes were substituted by the sense oligo-DNA probes in negative controls. After washing 3 times in $2 \mathrm{X} \mathrm{SSC}, 0.5 \mathrm{X} \mathrm{SSC}$ and $0.2 \mathrm{X} \mathrm{SSC}$ at $37^{\circ} \mathrm{C}$, slides were incubated with a protein blocker for $20 \mathrm{~min}$ at room temperature. Anti-digoxin antibody was pipetted onto slides for $60 \mathrm{~min}$ incubation at $37^{\circ} \mathrm{C}$. Washing 3 times with $0.5 \mathrm{M}$ PBS, biotinylated link antibody was added to the slides, which were further incubated at $37^{\circ} \mathrm{C}$ for $30 \mathrm{~min}$ and then washed 3 times with $0.5 \mathrm{M}$ PBS. The slides were incubated with a streptavidin-biotin-peroxidase complex at $37^{\circ} \mathrm{C}$ for $20 \mathrm{~min}$, washed 3 times in $0.5 \mathrm{M} \mathrm{PBS}$, and immersed in $\mathrm{DAB}$ reagent for a color reaction. Finally, the sections were counterstained with hematoxylin and mounted; brown and yellow colors indicated positive results. 


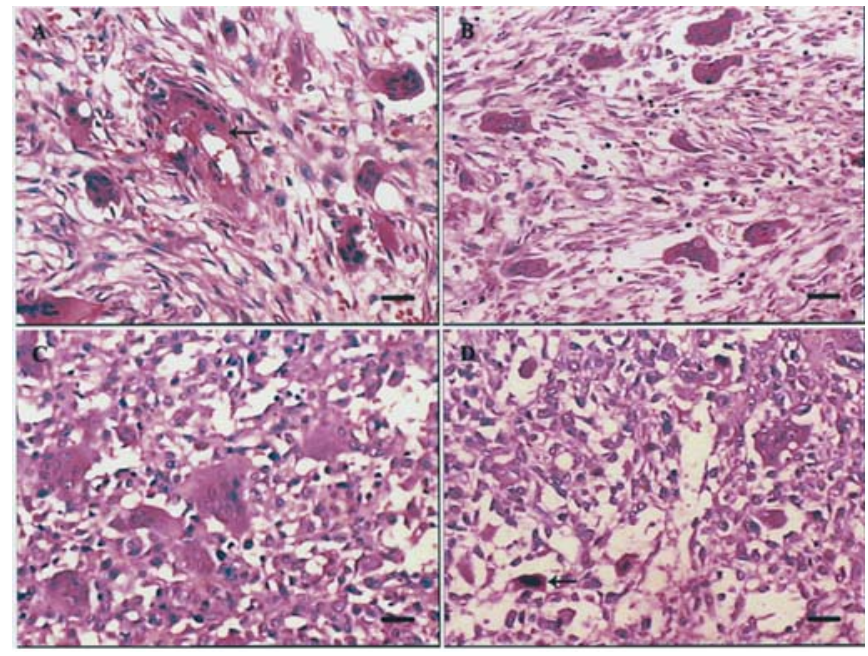

Figure 1. H\&E-stained sections showing multinuclear giant cells scattered randomly throughout the cellular and fibrous tissue in CBM (A), CGCG (B) and GCT (C and D). (A) The eosinophilic perivascular cuff (arrow) was seen in CBM. (D) Atypical mitoses of the mononuclear cell (arrow) was observed in GCT. Bar, $50 \mu \mathrm{m}$.

TRAP enzyme histochemical staining. TRAP activity was detected by use of an acid phosphatase leukocyte kit (Sigma). After deparaffinization, hydration and washing in PBS, the serial sections were incubated with a mixture of $4 \mathrm{mg}$ of naphthol AS-BI phosphate and $24 \mathrm{mg}$ red violet salt was diluted in $30 \mathrm{ml}$ of $0.1 \mathrm{~mol} / 1$ acetate buffer $(\mathrm{pH} 5.0)$ containing $0.3 \mathrm{mmol} / 1$ tartrate at $37^{\circ} \mathrm{C}$ for $30 \mathrm{~min}$. Sections were counterstained with methylene blue and mounted.

Quantitative image measurement and statistical analysis. Quantitative evaluation of each section was performed using a pathology image-analysis system (HPIAS-2000; Qianping Co., Wuhan, China). Briefly, the slides were captured using a computer system (Power Macintosh 7600/200; Apple, USA) and CCD camera (CS530MP; Olympus, Tokyo, Japan) interfaced with a digital imaging microscope (BX50; Olympus, Tokyo, Japan). For sections of each case stained with H\&E, giant cells in 25 random high-power fields (HPF) at a x400 magnification were measured with the digitizing tablet. The assessed parameters included the mean of areas for the giant cell profiles, mean number of nuclei per giant cell, fractional surface area (FSA) occupied by the giant cells in 25 fields, and relative size index. The latter was calculated using FSA x 100/number of giant cells in $25 \mathrm{HPF}$. The average staining intensity (ASI) for the c-Src protein, c-Src mRNA expression and TRAP staining were examined on pictures obtained at a x200 magnification by the digitizing frame grabber. The percentage of positive MGCs and mononuclear cells among CBM, CGCG and GCT was calculated by counting $1000 \mathrm{MGCs}$ and mononuclear cells, respectively, also with a x200 magnification. During the examination, all slides were detected in one session in which lighting conditions were kept constant, and the same settings were used in the HPIAS-2000 system for all sections. Measurements were made by two investigators who were not aware of the site of origin or diagnosis of the lesions.

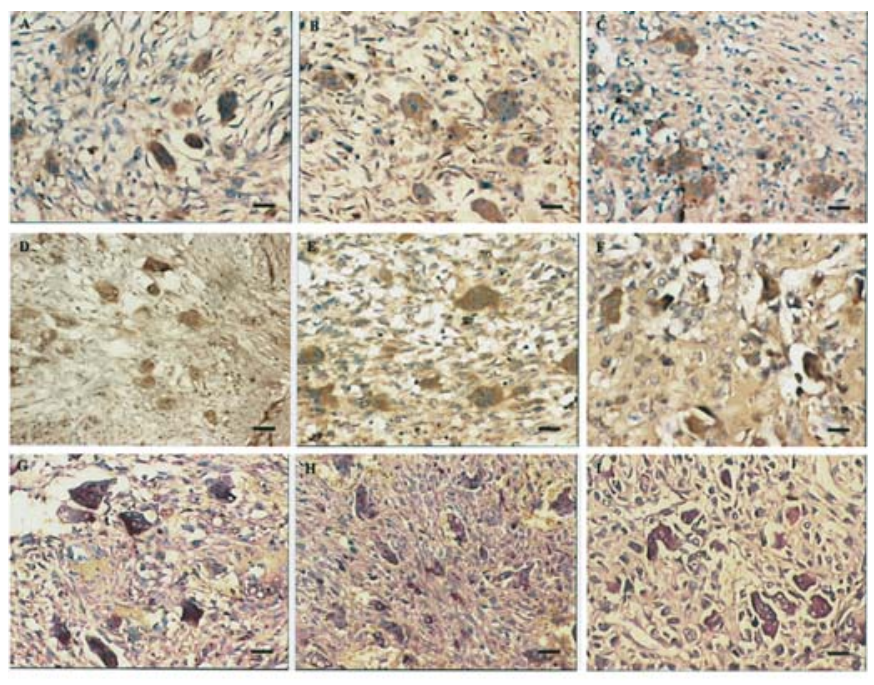

Figure 2. Immunohistochemistry (A-C), in situ hybridization (D-E) and TRAP staining (G-I) for CBM, CGCG of jaws and GCT of long bones showing MGCs and a fraction of round mononuclear stromal cells expressed c-Src protein, c-Src mRNA, and positively stained TRAP (A, D, G, CBM; B, E, H, CGCG; C, F, I, GCT). Bar, $50 \mu \mathrm{m}$.

All data are expressed as mean \pm SD and were statistically analyzed with one-way ANOVA to determine differences among the three lesions by two separate observers blinded to the clinical materials. Pearson's method was used to determine the correlation between the expression of $\mathrm{c}$-Src protein and mRNA in CBM, CGCG and GCT. The level of significance was set at $\mathrm{P}<0.05$.

\section{Results}

Clinical features. The clinical data for all reviewed cases with the three diseases, including the age range, mean age, gender information, familial history, and location of the lesion, are listed in Table I. The mean age of the patients with CBM, CGCG and GCT was 9.1 $\pm 3.1,21.5 \pm 4.8$ and $23.5 \pm 4.1$ years, respectively. There was a statistical difference among them $(\mathrm{P}<0.05)$. In comparison with the age of patients with CGCG and GCT, the age of the patients with CBM was much younger. The ratio of males to females was nearly even for the three diseases.

Histological findings and giant cell quantitative data. Microscopic examination showed that the histological features in these three types of giant cell-containing lesions were similar (Fig. 1A-D). A large number of MGCs were scattered in a loose, fibrous connective tissue stroma containing a large number of fibroblasts and some small blood vessels. The eosinophilic perivascular cuff was seen in 2 of 12 cases of CBM (Fig. 1A). Atypical mitoses of the mononuclear cells (Fig. 1D) and foci of necrosis (data not shown) were observed in only 5 of 37 cases of GCT. Table II shows the mean of areas for the giant cell profiles, mean number of nuclei per giant cell, mean FSA, and relative size index among the three lesions. No statistical significance was shown among values in the investigated groups. 
Table II. Cytometric analysis of CBM, CGCG and GCT.

\begin{tabular}{lccccc}
\hline & \multicolumn{2}{l}{ Profile areas of MGCs $\left(\mu \mathrm{m}^{2}\right)$} & & Mean number \\
\cline { 2 - 7 } Groups & Range & Mean \pm SD & $\begin{array}{c}\text { Fractional surface area } \\
\text { of nuclei per MGC } \pm \text { SD) }\end{array}$ & $\begin{array}{c}\text { Relative size index } \\
(\mathrm{mean} \pm \mathrm{SD})\end{array}$ \\
\hline CBM & $378-3785$ & $1179 \pm 632$ & $8.82 \pm 1.21$ & $0.054 \pm 0.041$ & $0.174 \pm 0.065$ \\
CGCG & $413-3668$ & $1128 \pm 512$ & $7.81 \pm 2.11$ & $0.048 \pm 0.032$ & $0.165 \pm 0.054$ \\
GCT & $338-3860$ & $1236 \pm 629$ & $9.21 \pm 2.54$ & $0.067 \pm 0.052$ & $0.215 \pm 0.078$ \\
\hline
\end{tabular}

$\mathrm{SD}$, standard deviation. No significant differences existed in all the parameters among the three lesions.

Table III. Summary of expression of c-Src protein, c-Src mRNA, and TRAP staining (mean \pm SD).

\begin{tabular}{|c|c|c|c|c|c|c|c|c|c|}
\hline \multirow[b]{2}{*}{ Lesions } & \multicolumn{3}{|c|}{$\begin{array}{l}\text { Average staining intensity } \\
\text { (ASI) of positive cells }\end{array}$} & \multicolumn{3}{|c|}{$\begin{array}{c}\text { Percentage of positive } \\
\text { MGCs }(\%)\end{array}$} & \multicolumn{3}{|c|}{$\begin{array}{c}\text { Percentage of positive } \\
\text { mononuclear stromal cells }(\%)\end{array}$} \\
\hline & $\begin{array}{l}\mathrm{c}-\mathrm{Src} \\
\text { protein }\end{array}$ & $\begin{array}{l}\mathrm{c}-\mathrm{Src} \\
\mathrm{mRNA}\end{array}$ & $\begin{array}{l}\text { TRAP } \\
\text { staining }\end{array}$ & $\begin{array}{l}\text { c-Src } \\
\text { protein }\end{array}$ & $\begin{array}{l}\mathrm{c}-\mathrm{Src} \\
\text { mRNA }\end{array}$ & $\begin{array}{l}\text { TRAP } \\
\text { staining }\end{array}$ & $\begin{array}{l}\text { c-Src } \\
\text { protein }\end{array}$ & $\begin{array}{l}\mathrm{c}-\mathrm{Src} \\
\mathrm{mRNA}\end{array}$ & $\begin{array}{l}\text { TRAP } \\
\text { staining }\end{array}$ \\
\hline $\mathrm{CBM}(\mathrm{n}=12)$ & $0.23 \pm 0.06$ & $0.21 \pm 0.07$ & $0.38 \pm 0.09$ & $90.5 \pm 4.5$ & $91.6 \pm 3.6$ & $90.1 \pm 1.9$ & $12.5 \pm 3.8$ & $14.5 \pm 4.4$ & $13.1 \pm 3.2$ \\
\hline CGCG $(n=24)$ & $0.27 \pm 0.05$ & $0.24 \pm 0.06$ & $0.40 \pm 0.08$ & $91.2 \pm 3.8$ & $92.1 \pm 4.4$ & $88.5 \pm 2.3$ & $11.8 \pm 2.6$ & $12.8 \pm 4.9$ & $14.1 \pm 4.6$ \\
\hline GCT $(n=37)$ & $0.31 \pm 0.07$ & $0.28 \pm 0.08$ & $0.36 \pm 0.10$ & $93.5 \pm 2.1$ & $92.8 \pm 2.9$ & $89.1 \pm 1.8$ & $13.9 \pm 3.1$ & $12.9 \pm 4.1$ & $13.3 \pm 3.5$ \\
\hline
\end{tabular}

No significant differences existed in the ASI positive cells and the percentage of the positive MGCs and mononuclear stromal cells among the three lesions for c-Src protein, mRNA and TRAP staining (one-way ANOVA, P>0.05). A significant correlation existed between the protein and mRNA level for $\mathrm{c}-\mathrm{Src}$ among the three lesion types (Pearson's method: $\mathrm{r}=0.8046$ in CBM, $\mathrm{r}=0.8147$ in CGCG, and $\mathrm{r}=0.7145$ in GCT; $\mathrm{P}<0.01)$.

Expression of c-Src protein, $c$-Src mRNA and TRAP staining. The localization of $\mathrm{c}$-Src protein and brown granular reaction products of c-Src mRNA was diffused/distributed in the cytoplasm of the giant cells and in about $10-15 \%$ of roundshaped mononuclear stromal cells, while no positive signals were found in the spindle-shaped mononuclear stromal cells in the three lesions (Fig. 2A-F). There were no positive signals detected in the negative controls. The multinuclear giant cells in CBM, CGCG and GCT were strongly positive for TRAP staining (Fig. 2G-I). Approximately 10-15\% of round-shaped mononuclear cells were also TRAP-positive, and tended to surround TRAP-positive MGCs. In the histometrical analysis, the ASI of cells with positive signals and percentage of positive MGCs and mononuclear stromal cells for c-Src protein, c-Src mRNA and TRAP staining are shown in Table III. There were no significant differences among the CBM, CGCG and GCT groups. A significant correlation was shown between c-Src protein and mRNA in the three giant-cell-rich lesions.

\section{Discussion}

Cherubism generally occurs between the ages of 2 and 4, often with a hereditary tendency and bilateral involvement (15). No familial history was found to be associated with CGCG and GCT, and most patients were aged between 10 and 30 years for CGCG and 20-40 years for GCT (6). In the present study, the average age at the time of initial diagnosis was $9.1,21.5$ and 23.5 years for the patients with CBM,
CGCG of the jaw and GCT of the long bone, respectively. The data are similar to other results for CGCG and GCT, but the age of patients with CBM appears to be older than that in previous reports $(10,16,17)$. It should be noted that the age of onset in CBM is still much younger than that of other giantcell-rich lesions. The difference in age distribution and clinical features suggests that CBM may be a biologically different lesion. In addition, female predilection for CGCG and GCT was reported in earlier findings (6). However, in our study, neither CBM nor CGCG or GCT exhibited a predilection for females or males.

CBM, CGCG and GCT are clinically different, but are all giant cell-containing lesions. Their etiology and pathogenesis remain unclear and controversial. In our study, the characteristic multinuclear giant cells presented in a stromal tissue containing round- and spindle-shaped mononuclear cells within the three types of lesions. Although the mechanism underlying the interrelations between cellular components and the formation of MGCs remains unknown, the lesions show a common feature of excessive bone resorption restricted to the long bone in GCT and to the jaw in CBM and CGCG.

The histological appearance of the three lesions is similar, thereby creating difficulties in differentiating the diagnosis. Cytological features were previously compared between CGCG and GCT, and the consentaneous findings considered that the giant cells of the GCT presented more nuclei than those of the CGCG, but comparing the size of giant cells between these two lesions showed converse results (10). In our study, the three clinically different diseases of CBM, CGCG, and 
GCT were cytometrically compared. To determine whether there are any quantitative differences among the three lesions, the fractional surface area occupied by the giant cells and relative size index were investigated in addition to the areas of the giant cell profiles and mean number of nuclei per giant cell. No significant difference was revealed by the comprehensive cytometric analysis for CBM, CGCG, and GCT. Although the presence of eosinophilic cuffing in CBM and foci of necrosis in GCT were considered as specific features in some reports $(10,17)$, our study exhibited these manifestations in only 2 cases (2/12) of CBM and 5 cases (5/37) of GCT. Thus, the giant cell-rich lesions of bone have overlapping cytological features and no characteristic histological manifestations. The combined evaluation of clinical and radiographic findings will be needed to help distinguish these entities and reach a correct diagnosis.

In the present study, the data demonstrated that c-Src expression in osteoclast-like giant cells and some normal stromal cells is associated with the three investigated lesion types, despite differences in their etiology and clinical behavior. c-Src was first defined as the normal cellular counterpart of the transforming gene of Rous Sarcoma Virus and overexpressed in a variety of human tumors (18). Increased c-Src expression and/or activity has previously been found in human carcinoma cells such as breast, colon, lung and bladder carcinomas, which indicated that the overexpression of c-Src might be associated with hyperproliferation in some abnormal tissues (19-22). Research data suggest that Src can be activated downstream from RANK, a member of the tumor necrosis factor (TNF) receptor superfamily involved in osteoclast formation, survival, and function (23). RANK signaling is mediated by cytoplasmic factors that activate downstream signaling pathways. At least five different signaling cascades, including the Src pathway downstream of RANK signaling, are induced during osteoclastogenesis and activation (24). Previous investigations have indicated that RANK expression has a role in the formation of MGCs in CBM, CGCG, and GCT and in the pathogenesis of these diseases $(11,12)$. In the present study, the expression of c-Src was first found to be present in CBM and CGCG of the jaw, and GCT of the long bone. After analysis at both the mRNA and protein level, no significant difference for c-Src-positive cells was revealed among the three lesions. The results suggest that c-Src may be involved in the formation of MGCs in these lesions, and indicate that the c-Src pathway, a signaling pathway down-stream of RANK, may be a common signaling cascade during osteoclastogenesis in the MGC-containing lesions in our study, regardless of location either in the jaw or long bone.

There is controversy regarding the formation of MGCs in these giant cell-containing lesions. It was proposed that the giant cells are formed by the fusion of stromal cells, while others explained that they may originate from endothelial cells of capillaries or fibroblasts $(7,11)$. Previous research suggested that mononuclear stromal cells might be attracted from peripheral blood and may be capable of further differentiation to MGCs in the GCT of the long bone (25). In our study, both the MGCs and fraction of round-shaped mononuclear cells expressed c-Src, and stained positive for TRAP in these three lesions. The results support hypotheses that the osteoclast-like MGCs in these lesions may arise from the fusion of the mononuclear component, and round-shaped mononuclear cells may be osteoclast progenitors, not only in GCT of the long bone, but also in CBM and CGCG of the jaw.

Bone homeostasis reflects the balance between bone formation by the osteoblast and bone resorption by the osteoclast. In CBM, CGCG and GCT, there is excessive bone resorption restricted to the jaw or long bone. Blocking RANK/ RANKL activity has been found to decrease bone destruction in animal models $(13,26)$, and therapeutics using this strategy may also be useful for CBM, CGCG and GCT in which the Src kinase has been implicated. It is important to note that osteoclasts provide a model system for understanding the Src function in a physiologic setting. The present study indicates that the association of Src with MGCs in the three lesions might provide a new therapeutic target for osteoclast inhibition.

\section{Acknowledgements}

This work was supported by grant no. 2004BA720A24 from Mega-Projects of Science Research for the 10th Five-Year Plan, the Ministry of Science and Technology of China, and grant no. 2004ABC004 from the Innovative Research Team of Hubei Province.

\section{References}

1. Jones WA: Familial multilocular cysts of the jaws. Am J Cancer 17: 946-950, 1933.

2. Kramer IRH, Pindborg JJ and Shear M: World Health Organization Histological Typing of Odontogenic Tumors. 2nd edition. Springer-Verlag, Berlin, p31, 1992.

3. Lo B, Faiyaz-UI-Haque M, Kennedy S, Aviv R, Tsui LC and Teebi AS: Novel mutation in the gene encoding c-Abl-binding protein SH3BP2 causes cherubism. Am J Med Genet 121A: 37-40, 2003.

4. Imai Y, Kanno K, Moriya T, Kayano S, Seino H, Matsubara Y and Yamada A: A missense mutation in the SH3BP2 gene on chromosome 4p16.3 found in a case of nonfamilial cherubism. Cleft Palate Craniofac J 40: 632-638, 2003.

5. Özkan Y, Varol A, Turker N, Aksakalli N and Basa S: Clinical and radiological evaluation of cherubism: a sporadic case report and review of the literature. Int J Pediatr Otorhinolaryngol 67: 1005-1012, 2003.

6. Kaugars GE, Niamtu J and Svirsky JA: Cherubism: diagnosis, treatment, and comparison with central giant cell granulomas and giant cell tumors. Oral Surg Oral Med Oral Pathol 73: 369-374, 1992.

7. Itonaga I, Hussein I, Kudo O, Sabokbar A, Watt-Smith S, Ferguson D and Athanasou NA: Cellular mechanisms of osteoclast formation and lacunar resorption in giant cell granuloma of the jaw. J Oral Pathol Med 32: 224-231, 2003.

8. Robinson D, Segal M and Nevo Z: Giant cell tumor of bone: the role of fibroblast growth factor 3 positive mesenchymal stem cells in its pathogenesis. Pathobiology 70: 333-342, 2002-03.

9. Oda Y, Sakamoto A, Saito T, Matsuda S, Tanaka K, Iwamoto Y and Tsuneyoshi M: Secondary malignant giant-cell tumour of bone: molecular abnormalities of p53 and H-ras gene correlated with malignant transformation. Histopathology 39: 629-637, 2001.

10. Auclair PL, Cuenin P, Kratochvil FJ, Slater LJ and Ellis GL: A clinical and histomorphologic comparison of the central giant cell granuloma and the giant cell tumor. Oral Surg Oral Med Oral Pathol 66: 197-208, 1988.

11. Liu B, Yu SF and Li TJ: Multinucleated giant cells in various forms of giant cell containing lesions of the jaws express features of osteoclasts. J Oral Pathol Med 32: 367-375, 2003.

12. Roux S, Amazit L, Meduri G, Guiochon-Mantel A, Milgrom E and Mariette X: RANK (receptor activator of nuclear factor kappa B) and RANK ligand are expressed in giant cell tumors of bone. Am J Clin Pathol 117: 210-216, 2002. 
13. Armstrong AP, Tometsko ME, Glaccum M, Sutherland CL, Cosman D and Dougall WC: A RANK/TRAF6-dependent signal transduction pathway is essential for osteoclast cytoskeletal organization and resorptive function. J Biol Chem 277: 44347-44356, 2002.

14. Xing L, Venegas AM, Chen A, Garrett-Beal L, Boyce BF, Varmus HE and Schwartzberg PL: Genetic evidence for a role for Src family kinases in TNF family receptor signaling and cell survival. Genes Dev 15: 241-253, 2001.

15. Kozakiewicz M, Perczynska-Partyka W and Kobos J: Cherubismclinical picture and treatment. Oral Dis 7: 123-130, 2001.

16. Von Wowern N: Cherubism: a 36-year long term follow-up of 2 generations in different families and review of the literature. Oral Surg Oral Med Oral Pathol Oral Radiol Endod 90: 765-772, 2000.

17. Ongole R, Pillai RS and Pai KM: Cherubism in siblings: a case report. J Can Dent Assoc 69: 150-154, 2003.

18. Abram CL and Courtneidge SA: Review: Src family tyrosine kinases and growth factor signaling. Exp Cell Res 254: 1-13, 2000.

19. Verbeek BS, Vroom TM, Adriaansen-Slot SS, Geertzema JG, Ottenhoff-Kalff AE, Hennipman A and Rijksen G: C-Src protein expression is increased in human breast cancer. An immunohistochemical and biochemical analysis. J Pathol 180: 383-388, 1996.

20. Cartwright CA, Meisler AI and Eckhart W: Activation of the pp60 6 -src protein kinase is an early event in colon carcinogenesis. Proc Natl Acad Sci USA 87: 558-562, 1990.
21. Mazurenko NN, Kogan EA, Zborovskaya IB and Kisseljov FL: Expression of pp60 $0^{\mathrm{c}-\mathrm{src}}$ in human small cell and non-small cell lung carcinomas. Eur J Cancer 28: 372-377, 1992.

22. Fanning P, Bulovas K, Saini KS, Libertino JA, Joyce AD and Summerhayes IC: Elevated expression of pp60 $0^{\mathrm{c}-\mathrm{src}}$ in low grade human bladder carcinomas. Cancer Res 52: 1457-1462, 1992.

23. Li J, Sarosi I, Yan XQ, Morony S, Capparelli C, Tan HL, McCabe S, Elliott R, Scully S, Van G, Kaufman S, Juan SC, Sun Y, Tarpley J, Martin L, Christensen K, McCabe J, Kostenuik P, Hsu H, Fletcher F, Dunstan CR, Lacey DL and Boyle WJ: RANK is the intrinsic hematopoietic cell surface receptor that controls osteoclastogenesis and regulation of bone mass and calcium metabolism. Proc Natl Acad Sci USA 97: $1566-1571,2000$

24. Boyle WJ, Simonet WS and Lacey DL: Osteoclast differentiation and activation. Nature 423: 337-342, 2003.

25. Miyamoto N, Higuchi Y, Tajima M, Ito M, Tsurudome M, Nishio M, Kawano M, Sudo A, Uchida A and Ito Y: Spindleshaped cells derived from giant-cell tumor of bone support differentiation of blood monocytes to osteoclast-like cells. J Orthop Res 18: 647-654, 2000.

26. Kong YY, Feige U, Sarosi I, Bolon B, Tafuri A, Morony S, Capparelli C, Li J, Elliott R, McCabe S, Wong T, Campagnuolo G, Moran E, Bogoch ER, Van G, Nguyen LT, Ohashi PS, Lacey DL, Fish E, Boyle WJ and Penninger JM: Activated T cells regulate bone loss and joint destruction in adjuvant arthritis through osteoprotegerin ligand. Nature 402: 304-309, 1999. 